\title{
Selective dysventilation syndrome: Anatomical and clinical features
}

\author{
Selektif disventilasyon sendromu: Anatomik ve klinik özellikler
}

\author{
Filiz Gülüstan' ${ }^{10}$, Emine $\operatorname{Demir}^{2}$ (I) \\ ${ }^{1}$ Department of Otolaryngology, University of Health Sciences, Bakırköy Dr. Sadi Konuk Training and Research Hospital, Istanbul, Turkey \\ ${ }^{2}$ Department of Otolaryngology, Recep Tayyip Erdoğan University, Faculty of Medicine, Rize, Turkey
}

\begin{abstract}
Objectives: This study aims to evaluate the clinical features of patients who underwent surgery for isolated attic cholesteatoma and were diagnosed with selective dysventilation syndrome (SDVS).

Patients and Methods: Pre- and postoperative clinical data of 33 SDVS patients (20 males, 13 females; mean age 31.8 years; range, 17 to 56 years) operated on for isolated attic cholesteatoma between January 2016 and September 2017 were retrospectively examined and recorded. Mastoid development was evaluated from preoperative temporal bone computed tomography images. Pre- and postoperative first year pure tone audiometry test results were recorded. Based on intraoperative findings, patients were divided into three groups according to epitympanic diaphragm/attic aeration pattern. The data of these three groups were compared statistically.

Results: There were 17 type A (tympanic istmus blockage+complete tensor fold), 10 type B (tympanic istmus blockage+attical vertical blockage+incomplete/complete tensor fold) and six type $\mathrm{C}$ (complete epidermization of the attic+complete tensor fold) patients. The most common complaint in all groups was otorrhea. In groups A and B, mild retraction was generally observed in the tympanic membrane, whereas advanced retraction was observed in group $C(p=0.002)$. There was evident mastoid hypopneumatization in each group and mastoid development was significantly worse in group $C(p=0.023)$. In addition, facial dehiscence and recurrence rates were significantly higher in group $\mathrm{C}(\mathrm{p}=0.006, \mathrm{p}=0.011$, respectively).

Conclusion: Selective dysventilation in the epitympanum may cause chronic middle ear diseases such as cholesteatoma behind mild retraction. The mastoid hypopneumatization caused by dysventilation is also undeniable in triggering this condition. During the surgery, particularly in isolated epitympanum pathologies, epitympanic diaphragm should be carefully evaluated.

Keywords: Epitympanum, Eustachian tube, retraction, selective dysventilation, tympanic istmus.
\end{abstract}

$\ddot{O} Z$

Amaç: Bu çalışmada izole attik kolesteatomu nedeniyle cerrahi geçirip selektif disventilasyon sendromu (SDVS) tanısı konulan hastaların klinik özellikleri değerlendirildi.

Hastalar ve Yöntemler: Ocak 2016 - Eylül 2017 tarihleri arasında izole attik kolesteatomu nedeniyle ameliyat edilen 33 SDVS hastasının (20 erkek, 13 kadın; ort. yaş 31.8 yıl; dağılım, 17-56 yıl) ameliyat öncesi ve sonrası klinik verileri retrospektif olarak incelendi ve kaydedildi. Mastoid gelişim ameliyat öncesi temporal kemik bilgisayarlı tomografi görüntülerinden değerlendirildi. Ameliyat öncesi ve sonrası birinci yıl saf ses odyometri sonuçları kaydedildi. Ameliyat sırasında elde edilen bulgulara dayanılarak hastalar epitimpanik diyafram/attik havalanma paternine göre üç gruba ayrıldı. Bu üç grubun verileri istatistiksel olarak karşılaştırıldı.

Bulgular: On yedi tip A (timpanik istmus blokaj1+tam tensör fold), 10 tip B (timpanik istmus blokaj1+attik dikey blokaj1+tam olmayan/tam tensör fold) ve altı tip C (attik tam epidermizasyonu+tam tensor fold) hasta vardı. Tüm gruplarda en yaygın yakınma otore idi. Grup A ve B'de genellikle timpan membranda hafif retraksiyon gözlenirken grup C'de ileri düzey retraksiyon gözlenlendi $(\mathrm{p}=0.002)$. Her grupta belirgin mastoid hipopnömotizasyon vardı ve mastoid gelişim grup C'de anlamlı olarak daha kötüydü $(\mathrm{p}=0.023)$. Ayrıca, fasiyal dehissans ve nüks oranları grup C'de anlamlı olarak daha yüksekti (sırasıyla, $\mathrm{p}=0.006, \mathrm{p}=0.011$ ).

Sonuç: Epitimpanumda selektif disventilasyon, hafif retraksiyon arkasında kolesteatom gibi kronik orta kulak hastalıklarına neden olabilir. Bu durumun tetiklenmesinde disventilasyonun neden olduğu mastoid hipopnömotizasyonun katkısı yadsınamaz. Cerrahi sırasında, özellikle izole epitimpanum patolojilerinde, epitimpanik diyafram dikkatle değerlendirilmelidir.

Anahtar sözcükler: Epitimpanum, östaki tüpü, retraksiyon, selektif disventilasyon, timpanik istmus.

Received: December 23, 2019 Accepted: May 25, 2020 Published online: June 11, 2020

Correspondence: Filiz Gülüstan, MD. SBÜ Bakırköy Dr. Sadi Konuk Eğitim ve Araştırma Hastanesi, Kulak Burun Boğaz Kliniği, 34147 Bakırköy, İstanbul, Türkiye. e-mail: filizyirci@hotmail.com 
The role of the Eustachian tube (ET) is very important in ventilation and maintaining atmospheric pressure of the middle ear. Dysfunction of ET disrupts tympanic ventilation and paves the way for chronic inflammatory diseases of the middle ear such as retraction, adhesive otitis and cholesteatoma. ${ }^{[1]}$ However, middle ear aeration and pressure balance are not only associated with ET function but are also due to gas exchange of the mastoid mucosa. Ensuring the connection between ET and mastoid mucosa is important for maintaining the aeration and pressure balance of the tympanic compartments. ${ }^{[2]}$ Understanding the development of tympanic compartments and folds, and their connections, provides insight into the development of chronic middle ear diseases. Therefore, anatomical features and functions of tympanic compartments and folds have attracted great interest since the $1800 \mathrm{s.}^{[3]}$

For the first time in 1945, Chatellier and Lemoine ${ }^{[4]}$ introduced the concept of 'epitympanic diaphragm', which plays an important role in the development of tympanic ventilation. The epitympanic diaphragm is formed by structures and folds at the base of the epitympanum. In the 1990s, Palva and Ramsay $^{[5]}$ and Palva and Johnsson ${ }^{[6]}$ described the tympanic istmus as an opening in the tympanic diaphragm, located between the tensor tympani tendon and pyramidal eminence, and as a main ventilation pathway for mastoid cells and epitympanum. The generally accepted tympanic isthmus is divided into anterior tympanic isthmus and posterior tympanic isthmus. The posterior tympanic isthmus located behind the incus short crus, which is usually blocked by the small posterior incudal fold, has a limited role in middle ear ventilation. The term tympanic isthmus is mainly used for the anterior tympanic isthmus and, it is the area between the stapes anterior crus and the tensor tympani tendon. Aimi ${ }^{[7]}$ defined the tympanic isthmus as a narrow passage between the tubotympanic cavity and the atticomastoid regions. This area is the major route of protympanum, mastoid and epitympanic area ventilation. Tensor fold and incudomalleolar fold, which are alternative routes of ventilation, may also have patency. However, these two pathways are closed in the majority of people and the only ventilation route leading to the epitympanum is tympanic isthmus. ${ }^{[8,9]}$ If complete tensor fold and incudomalleolar fold are accompanied by isthmus blockage and if there is a normal functioning ET, this situation is called selective dysventilation syndrome (SDVS). Syndrome occurs with the simultaneous presence of four conditions: retraction pocket or cholesteatoma in attic, type A tympanogram or normal tubal function test, complete epitympanic diaphragm, and isthmus blockage. ${ }^{[8]}$ This causes inadequate aeration of mastoid cells and epitympanic recess, causing chronic inflammatory disease such as retraction and cholesteatoma in the tympanic membrane. ${ }^{[3]}$ However, there are limited studies on SDVS and its clinical features. Further research on SDVS is needed to understand and manage the development of chronic middle ear diseases. In this study, we aimed to evaluate the clinical features of patients who underwent surgery for isolated attic cholesteatoma and were diagnosed with SDVS.

\section{PATIENTS AND METHODS}

The clinical records of 33 patients $(20$ males, 13 females; mean age 31.8 years; range, 17 to 56 years) operated on for attic cholesteatoma at Bakırköy Dr. Sadi Konuk Training and Research Hospital between January 2016 and September 2017 and diagnosed as SDVS by intraoperative findings were evaluated retrospectively. Inclusion criteria were patients with (i) preoperative temporal bone computed tomography (TBCT) images, (ii) normal tubal function tests, (iii) at least one year of follow-up, and (iv) pre- and postoperative first year audiometric evaluation. Exclusion criteria were (i) patients with cholesteatoma spreading to protympanic, mesotympanic or retrotympanic regions, (ii) those who did not follow-up or did not have sufficient follow-up period for the study, and (iii) those who underwent revision surgery. The study protocol was approved by the Bakırköy Dr. Sadi Konuk Training and Research Hospital Ethics Committee (protocol number: 2019/74). A written informed consent was obtained from each patient. The study was conducted in accordance with the principles of the Declaration of Helsinki.

Temporal bone computed tomography and ear diffusion magnetic resonance imaging (MRI) are routinely performed in all patients suspected of cholesteatoma. Patients with TBCT images and/or intraoperative findings consistent with intensive cholesteatoma were not included in our study. In addition, since we performed canal wall up tympanoplasty for limited attic cholesteatomas, we performed an ear diffusion MRI to evaluate the recurrence of cholesteatoma at sixth month, first year, and annually after. All patients included in our study had at least first year MRI. Demographic data of the patients (age, gender), presenting complaints (such as hearing loss, otorrhea), preoperative otoendoscopy findings, postoperative follow-up period from surgery to final control, whether recurrent retraction or cholesteatoma developed, and pre- and postoperative first year hearing test results were recorded. 
Preoperative otoendoscopic examinations were performed using $0^{\circ}$ and $4 \mathrm{~mm}$ endoscopes (Karl-Storz SE \& Co. KG, Tuttlingen, Germany). In all patients, the pars tensa of the tympanic membrane was intact and the examination findings of the pars flaccida were classified according to the classification of attic retraction of Tos and Poulsen ${ }^{[10]}$ as type 0: normal Shrapnell's membrane, type I: slight retraction with air between Shrapnell's membrane and the neck of the malleus, type II: retraction down to the malleus neck, type III: retraction behind the scutum with some bone resoption, and type IV: retraction behind the scutum with considerable bone resorption.

Routinely, when a patient is hospitalized for an otological disease or when cholesteatoma is suspected, preoperative TBCT is performed. Using the Japanese Otological Society's staging system, mastoid aeration was evaluated with preoperative TBCT and classified in four stages as MC0 (almost no cell growth), MC1 (cellular structures only around the mastoid antrum), MC2 (well developed cellular structures) or MC3 (cellular structures extending to the peri-labyrinthine area). ${ }^{[11]}$

All cases were operated under general anesthesia. Retroauricular approach was used for the surgical procedure. The tympanomeatal flap was elevated, then the flap was placed anteriorly and the middle ear was observed. The posterior border of the cholesteatoma was reached by drilling off the attic lateral wall retrogradely. The cholesteatoma sac was carefully elevated and removed from the epitympanic region. The epitympanic compartments and the incudomalleolar joint were made visible. The incus and head of malleus were removed and it was checked whether there was any pathological tissue remaining in the epitympanic region. Then tympanic istmus and tensor folds were evaluated. Mucosal folds causing blockage were removed and blockage was eliminated.
Mesotympanum, protympanic cavity, and ET orifice were evaluated. The operation was generally carried out with a microscope (Karl-Zeiss, Jena, Germany), while endoscopes (Karl-Storz, SE \& Co. KG, Tuttlingen, Germany, $0^{\circ}$ and $30^{\circ}, 2.7 \mathrm{~mm}$ ) were used to ensure visualization with proper angulation, if necessary.

Mucosal blockage between the stapes' anterior crus and tensor tympani tendon was evaluated as tympanic isthmus blockage. The tympanic istmus and tensor fold were evaluated from above by the wide atticotomy (Figure 1). Mucosal blockage was opened in tympanic istmus and tensor fold; then, ET and supratubal recess were evaluated. After the evaluation of these areas, the removed incus was reshaped and ossiculoplasty was achieved by placing it between the superstructure of the stapes and manubrium of the malleus in all patients. The defect in the lateral attic wall was reconstructed by composite tragal cartilage and then the operation was terminated. According to intraoperative endoscopic and microscopic findings, all cases were divided into three-type epitympanic diaphragm or attic aeration pattern using Marchioni et al.'s classification as type A: tympanic isthmus blockage with a complete tensor fold, type B: tympanic isthmus blockage with an attical vertical blockage, and with or without a complete tensor fold, type C: complete epidermization of the attic causing a blockage of the tympanic isthmus with a complete tensor fold. ${ }^{[3]}$

Audiometric analysis was performed in mean values of pure tone air conduction (AC) and bone conduction (BC) thresholds at $0.5,1,2$ and $4 \mathrm{kHz}$ using pre- and postoperative first year pure tone audiometry results. The difference between $\mathrm{AC}$ and $\mathrm{BC}$ averages was used to calculate air-bone gap $(\mathrm{ABG})$ in four-frequency puretone averages. In addition, hearing gains of all patients were calculated from pre- and postoperative ABG values. The tympanometry was performed at frequencies of 226-Hz. Type A tympanogram or Williams' test was
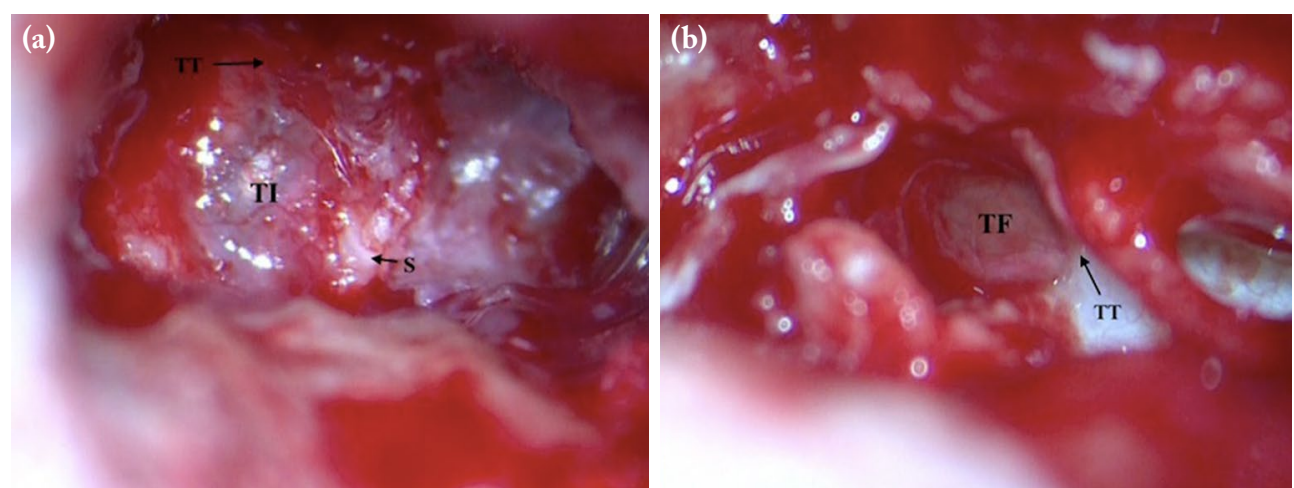

Figure 1. Right ear. (a) Endoscopic view of tympanic istmus in type A selective dysventilation syndrome (SDVS). (b) Endoscopic view of tensor fold in type A SDVS.

TT: Tensor tympani; TI: Tympanic istmus; S: Stapes; TF: Tensor fold. 


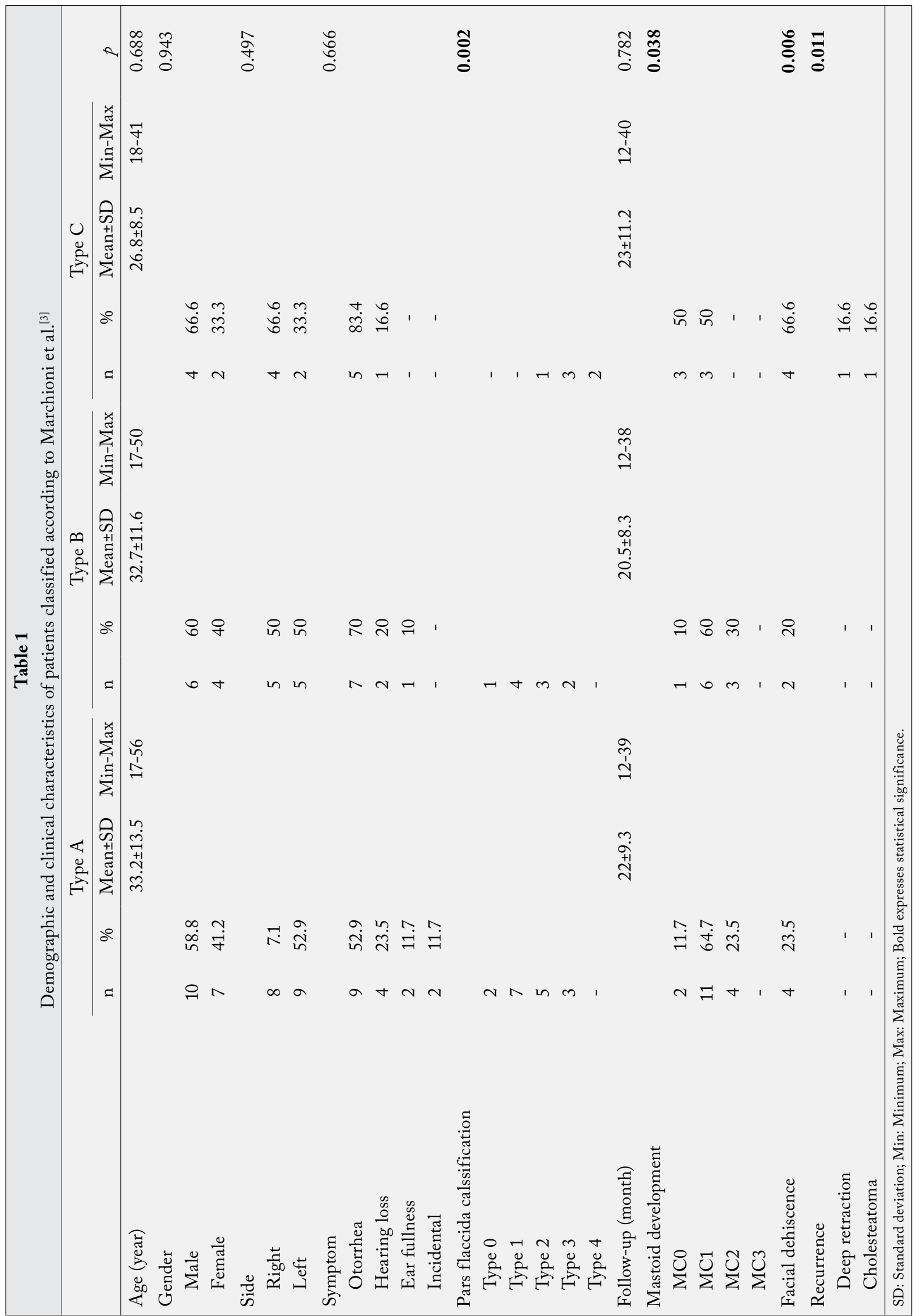




\begin{tabular}{|c|c|c|c|c|}
\hline Pre- and post & aring results, & $\begin{array}{l}\text { le } 2 \\
\text { btained fror } \\
\text { arison }\end{array}$ & postoperativ & gap \\
\hline & Type A & Type B & Type C & \\
\hline & Mean \pm SD & Mean \pm SD & Mean \pm SD & $p$ \\
\hline Preoperative & $26.3 \pm 10.3$ & $24.5 \pm 10.6$ & $25.8 \pm 11.5$ & \\
\hline Postoperative & $16.1 \pm 6$ & $15 \pm 6.6$ & $16.3 \pm 5.1$ & \\
\hline$P$ values & 0.004 & 0.017 & 0.044 & \\
\hline Hearing gain & $9.1 \pm 8.5$ & $10.3 \pm 9.8$ & $9.4 \pm 9.1$ & 0.9 \\
\hline
\end{tabular}

accepted as a normal tubal function test and all patients had normal tubal function tests. ${ }^{[12]}$

\section{Statistical analysis}

Statistical analysis was performed using the IBM SPSS version 20.0 software (IBM Corp., Armonk, NY, USA). Frequency analysis, Kruskal-Wallis test, and Mann-Whitney U test were performed to evaluate data. The statistical significance level was taken as $\mathrm{p}<0.05$.

\section{RESULTS}

There were 17 type A (tympanic istmus blockage+complete tensor fold), 10 type B (tympanic istmus blockage+attical vertical blockage+incomplete/ complete tensor fold) and six type C (complete epidermization of the attic+complete tensor fold) patients. Demographic data and clinical characteristics of the patients are shown in Table 1 . The ossicles were intact in all patients of all groups perioperatively.

One of the patients with type C SDVS had a deep retraction pocket at 24 months postoperatively. Recurrent cholesteatoma was detected by MRI and revision surgery was performed. Also, one patient with type C SDVS had a deep retraction pocket at 36 months postoperatively and no cholesteatoma was detected by MRI. The patient was referred to the revision surgery for retraction pocket; however, the patient preferred being followed-up instead of undergoing operation.

Mastoid pneumatization was significantly worse in type $\mathrm{C}$ patients than both type $\mathrm{A}$ and type $\mathrm{B}$ patients. The stage of attic retraction was significantly more advanced in type $\mathrm{C}$ than type $\mathrm{A}$ and type $\mathrm{B}$ patients. Facial dehiscence and recurrence rates were also significantly higher in type $\mathrm{C}$ patients.

Postoperative ABG values were significantly improved in all groups when compared with preoperative ABG. There was no significant difference between the hearing gains of the groups (Table 2).

\section{DISCUSSION}

Occlusion of the tympanic isthmus due to mucosal fold variations, inflammatory webs, and exudate causes chronic inflammatory middle ear diseases. ${ }^{[13]}$ In clinical practice, isolated pars flaccida retraction and/or limited attic cholesteatoma is considerable and in such case, usually mesotympanum and pars tensa are normal. Since ET plays a major role in mesotympanum ventilation, the fact that these areas are normal suggests that ET functions but there is a selective dysventilation in attic. ${ }^{[8]}$ This leads to retraction pocket followed by cholesteatoma. Epitympanic diaphragm should be carefully examined when performing surgery for these areas due to cholesteatoma or retraction. In particular, it should be kept in mind that the most common cause of SDVS is complete tympanic isthmus and tensor fold as seen in our study.

A functional ET is essential for optimal middle ear ventilation and maintaining pressure balance. However, middle ear aeration and pressure are not only associated with a functional ET but also depends on the transmucosal gas exchange from the mastoid mucosa. Mucosal gas exchange is also directly related to mastoid pneumatization pathways. The connection of these two ventilation and pressure balancing pathways should be ensured by the patency of the middle ear ventilation routes. ${ }^{[13]}$ Blocking of the ventilation routes prevents the development of mastoid cells. ${ }^{[8]}$ Marchioni et al. ${ }^{[3]}$ evaluated mastoid development of patients with SDVS and stated that the development of mastoid of patients with SDVS was poor. They reported that patients affected by attical aeration pattern type $\mathrm{C}$ present the worse degree of pneumatization. Similarly, in our study, mastoid sclerotization and hypopneumatization were generally present in patients and mastoid development was significantly worse in patients with complete epidermization than other patients. This suggests that the less the mastoid cells develop due to the blocking of ventilation routes, the 
worse the aeration is, and thus the chronic middle ear pathology will progress.

Lee et al. ${ }^{[14]}$ reported that the rate of development of attic cholesteatomas behind a tiny pars flaccida retraction or normal eardrum was higher than expected (7.7\%). $\operatorname{Tos}^{[15]}$ explained the mechanism of this situation as acquired-inclusion theory. According to this theory, inflammatory granulations in the pars flaccida retraction pocket disrupt tissue integrity and this epithelium heals again after treatment, while squamous epithelium remains in the epitympanum. This epithelium causes cholesteatoma. Therefore, patients with fullness in the ear and hearing loss should be carefully examined. The characteristics of the symptom should be questioned in detail. Lee et al. ${ }^{[14]}$ stated that each attic retraction should be examined in detail using endoscopy, microscopy and TBCT, even if it is tiny. We also evaluated the patients with normal tympanic membrane or tiny retraction by TBCT when we suspected the patient's symptoms. We performed MRI and observed cholesteatoma in patients with minimal soft tissue in posterior epitympanum in TBCT. Even if the tympanic membranes of patients with suspected cholesteatoma appear normal, anamnesis should be expanded and radiological examination should not be avoided if necessary because the diagnosis of limited cholesteatoma can be established early and can be removed with simple surgical procedures.

Marchioni et al. ${ }^{[3]}$ reported that only five of 22 SDVS patients had an erosion of the long process of the incus, while no erosion of the stapes and malleus was found. In our study, the ossicles were intact in all patients. We believe that this is related to the fact that we included only subjects of isolated attic cholesteatoma in our study and excluded the cases spreading to other areas of the middle ear. Although cholesteatoma did not spread to other areas of the middle ear in our cases, we had to remove the incus and malleus head since the cholesteatoma extended to the medial face of the ossicles and to investigate the anterior attic for the presence of a cholesteatoma. In order to examine this area and epitympanic diaphragm, it is correct not to hesitate in removing the ossicles if necessary since treatment of these areas may prevent the formation or recurrence of cholesteatoma. In addition, appropriate ossiculoplasty in the same session can give the middle ear the necessary volume and restore new ventilation routes. We achieved ossiculoplasty by placing reshaped incus between the superstructure of the stapes and manubrium of the malleus in all patients.

Although a small number of our patients presented with complaints of hearing loss, preoperative hearing tests had ABG. This suggests that hearing loss is ignored by the patients because the otorrhea is more prominent. Marchioni et al. ${ }^{[13]}$ reported that they achieved postoperative ABG gain in 18 of 19 SDVS patients. In our study, postoperative $A B G$ gain was achieved in all groups and no significant difference was detected between the groups in terms of $A B G$ gains. The presence of intact mesotympanum mucosa in our patients may have had a positive effect on the results of ossiculoplasty.

Recurrence rates observed after cholesteatoma surgery vary between $10 \%$ and $20 \% \cdot{ }^{[16]}$ In our study, no recurrence was seen in patients with type $A$ and type B SDVS, which may be related to the fact that we performed surgery with limited cholesteatoma in attic. However, in type C SDVS, recurrence of cholesteatoma developed in $16.6 \%$ and deep retraction pocket in $16.6 \%$. This may be related to the inadequate development of mastoid air cells in type C SDVS. Since we cannot improve mastoid development even if we restore the ventilation routes of the middle ear, the ongoing gas exchange problem in mastoid cells can trigger retraction and cause recurrence.

Facial canal dehiscence rates are around $20 \%$ in the normal population and this rate increases due to the defective effect of cholesteatoma. ${ }^{[17]}$ In our study's surgical findings, facial canal dehiscence was observed in $20 \%$ of patients with type A and type B SDVS, and $66.6 \%$ of patients with type C SDVS. Since cholesteatoma is limited in patients with type A and B SDVS, this dehiscence can be incidental regardless of cholesteatoma. However, high facial dehiscence rates in patients with type C SDVS may be associated with more advanced chronic middle ear pathologies. Contrary to our findings, Marchioni et al. ${ }^{[13]}$ reported that they did not identify facial canal dehiscence during surgery.

We performed the surgery mainly microscopically, but we evaluated tympanic compartments and folds with the help of endoscopy. Although the pathology can be removed microscopically, the endoscope allows us to better evaluate the hidden corners of the middle ear. Also, the entire surgery can be performed using an endoscope. The endoscope provides a clear visualization of the middle ear anatomy and a clear assessment of the middle ear ventilation routes during the operation.

The main limitation of our study may be that only patients with SDVS were evaluated, not all patients operated for isolated attic pathology. If we were able to evaluate all patients with attic pathology, the incidence and clinical differences of SDVS in chronic epitympanum pathologies could also be evaluated.

In conclusion, we observed that chronic epitympanic pathologies may be associated with SDVS. In addition, as the degree of dysventilation and chronic middle ear 
diseases increase, anatomical problems that may force surgical and postoperative results such as increased facial dehiscence rates and worse mastoid cell aeration may occur. Particularly in isolated attic pathologies, tympanic isthmus and tensor fold should be examined carefully during surgery. Restoring the ventilation pathways between epitympanum and mesotympanum may prevent postoperative disease recurrence.

\section{Declaration of conflicting interests}

The authors declared no conflicts of interest with respect to the authorship and/or publication of this article.

\section{Funding}

The authors received no financial support for the research and/or authorship of this article.

\section{REFERENCES}

1. Lin AC, Messner AH. Pediatric tympanoplasty: factors affecting success. Curr Opin Otolaryngol Head Neck Surg 2008;16:64-8.

2. Tanabe M, Takahashi H, Honjo I, Hasebe S. Gas exchange function of the middle ear in patients with otitis media with effusion. Eur Arch Otorhinolaryngol 1997;254:453-5.

3. Marchioni D, Mattioli F, Alicandri-Ciufelli M, Molteni G, Masoni F, Presutti L. Endoscopic evaluation of middle ear ventilation route blockage. Am J Otolaryngol 2010;31:453-66.

4. Chatellier HP, Lemoine J. Le diaphragme interatticotympanique du nouveau-né. Description de sa morphologie considérations sur son role pathogénique dans les otomastoidites cloisonnées du nourisson. Ann Otolaryngol Chir Cervicofac (Paris) 1945;13:534-66.
5. Palva T, Ramsay H. Incudal folds and epitympanic aeration. Am J Otol 1996;17:700-8.

6. Palva T, Johnsson LG. Epitympanic compartment surgical considerations: reevaluation. Am J Otol 1995;16:505-13.

7. Aimi K. The tympanic isthmus: its anatomy and clinical significance. Laryngoscope 1978;88:1067-81.

8. Marchioni D, Alicandri-Ciufelli M, Molteni G, Artioli FL, Genovese E, Presutti L. Selective epitympanic dysventilation syndrome. Laryngoscope 2010;120:1028-33.

9. Marchioni D, Piccinini A, Alicandri-Ciufelli M, Presutti L. Endoscopic anatomy and ventilation of the epitympanum. Otolaryngol Clin North Am 2013;46:165-78.

10. Tos M, Poulsen G. Attic retractions following secretory otitis. Acta Otolaryngol 1980;89:479-86.

11. Tono T, Sakagami M, Kojima H, Yamamoto Y, Matsuda $\mathrm{K}$, Komori M, et al. Staging and classification criteria for middle ear cholesteatoma proposed by the Japan Otological Society. Auris Nasus Larynx 2017;44:135-40.

12. Williams PS. A tympanometric pressure swallow test for assessment of eustachian tube function. Ann Otol Rhinol Laryngol 1975;84:339-43.

13. Marchioni D, Mattioli F, Alicandri-Ciufelli M, Presutti L. Endoscopic approach to tensor fold in patients with attic cholesteatoma. Acta Otolaryngol 2009;129:946-54.

14. Lee JH, Hong SM, Kim CW, Park YH, Baek SH. Attic cholesteatoma with tiny retraction of pars flaccida. Auris Nasus Larynx 2015;42:107-12.

15. Tos M. A new pathogenesis of mesotympanic (congenital) cholesteatoma. Laryngoscope 2000;110:1890-7.

16. Demir E, Atsal G, Yildirim O, Gulustan F, Dalgic A, Catli T, et al. Anatomical and frequencies-specific hearing results of retrograde mastoidectomy. Am J Otolaryngol 2019;40:372-6.

17. Gülüstan F, Aslan H, Songu M, Başoğlu MS, Katılmış H. Relationships between facial canal dehiscence and other intraoperative findings in chronic otitis media with cholesteatoma. Am J Otolaryngol 2014;35:791-5. 